Journal of Contemporary Research in Social Sciences

ISSN : 2641-0249

Vol. 3, No. 3, pp. 62-68.

2021

Publisher: Learning Gate

DOI: 10.33094/26410249.2021.33.62.68

(C) 2021 by the authors; licensee Learning Gate

\title{
Narrating Peer Assessment in a Group Task
}

\author{
Ramesh Rao Ramanaidu* \\ Institute of Teacher Education Ilmu Khas Campus, Malaysia. \\ Email: rameshrao08@yahoo.com (*Corresponding Author) \\ Edna Shamani Wellington \\ Institute of Teacher Education Ilmu Khas Campus, Malaysia. \\ Email:edna@ipgkik.edu.my
}

Received: 4 June 2021 ; Revised: 7 July 2021; Accepted: 29 July 2021 ; Published: 31 August 2021

\begin{abstract}
COVID19 interrupted many things in our life. To curb the spread of the virus, Movement Control Order (MOC) was enforced. Though face to face teaching and learning came to halt, was replaced by online learning. In the context of teaching and learning, teachers face a lot of problem in carrying out practices which were a norm before. This study intends to explore a group work, which was carried out during the pandemic. More importantly, on how to assess a group work, which was carried out online, is explored. The aim of this study is to reveal how a peer assessment, for a group task was carried out during the pandemic. Instead of students, 30 music pre-service teachers were involved in this study. They were divided into ten groups. These pre-service teachers were enrolled in a music pedagogy course. One of the tasks involves a group work. Each group is required to produce a video. The video is assessed based on three criteria i.e content of the video, creativity and group collaboration. Each pre-service teacher assessed another group's video using these criteria. Descriptive statistics and web analysis were used to analyse the scores given by the pre-service teachers. The result revealed that the component of creativity is viewed differently by many pre-service teachers, compared to the other two.
\end{abstract}

Keywords: Group work, Peer assessment, Web analysis, Group task, Online assessment, Music education, Teacher training.

\section{Introduction}

Practices which were a norm before the Covid 19 pandemic are fast becoming obsolete. Educationist have to evaluate and re-design approaches in teaching and learning (T\&L), to meet the demands of online learning and teaching. This study intends to explore one aspect of the $21^{\text {st }}$ century learning. A key component of the $21^{\text {st }}$ century learning is group work. Group work assessment strategies which are designed to engage students and provide the best possible learning experience, raises a number of important questions.

Besides increasing human interaction, group work enhances skills and knowledge of students. For many years, group tasks have been used in higher education as a learning and teaching strategy, and it is more prevalent now. Group work and collaborative learning, with or without associated assessment, has been the subject of considerable research and discussion in the higher education literature (Boud \& Falchikov, 2007; Davis, 1993; Falchikov, 2005). With the pandemic and movement control order (MCO), it was a challenge for teachers and students to carry out group related activities or assignments via online. Thus, forcing many teachers to stay away from group related tasks. Hopefully the approaches suggested and findings of this study could help teachers to execute group activities online.

In modern world, team work and collaboration among colleagues are important in achieving the organisation objective (Nikoleizig, Schmukle, Griebenow, \& Krause, 2021). In the context of teaching 
and learning, team work and collaboration among teachers are necessary in ensuring students' learning is maximized. Phrases such 'Professional Learning Communities" (PLC) and "Continuous Professional Development" (CPD) are aimed in ensuring team work and collaboration is practised. Beside administrators, even university professors could instigate and facilitate teacher's groups (Stanley, 2011). As such, many teacher educators resort to group based task when delivering a course.

Due to the MCO, face to face interaction almost came to a standstill. Nevertheless teaching and learning is not halted. In teacher training, lecturers resorted to conducting their lectures via online and offline. Forcing many pre-service teachers to work in silos. Being future music teachers, working in silos does not augur well for the development of professional knowledge. Working together on a specific task could provide the necessary opportunities for all to tap into each other's expertise and knowledge (Stanley, 2011). Task requiring group work is incorporated in which the skills and abilities of the preservice teachers are fostered and nurtured. In a study group, the members share a common goal and organise themselves in achieving the goal. Hence when choosing the team members, strengths, weakness and compatibility are given prominence.

Being future teachers, assessment and evaluation are part and parcel of teaching. Hence many courses offered in a teacher training programme, exposes pre-service teachers to assessment and evaluation. This scenario has become an important area of study in the current environment as the development of peer-assessment skills is becoming an increasingly important issue at teacher training institutions.

Music educators at teacher training institutions strive to guide their students to become excellent educators in many aspects of music education. Only when music teachers begin to apply metacognitive practices, their pedagogy skills would improve. Eventually their music students' performance would improve (Bathgate, Sims-Knight, \& Schunn, 2012).

Often, teacher training classes are instructor led and lack the opportunity for music pre-service teachers, a chance to practice self and peer assessment during classroom activities. This gap is also prevalent in the field of music education, therefore the aim of many music lecturers is to help their preservice teachers to become independent musicians who are capable of critiquing their own learning and assignment tasks and make improvements based on feedback received. Taking part in assessment is an opportunity for teacher trainees to develop self-regulating skills and developing a better comprehension of their own learning process and analyse their own behaviour (De Grez, Valcke, \& Roozen, 2012).

In terms of effective learners, Kılıç (2016) stated that effective learners have a realistic view about their own strengths and weaknesses and they can use knowledge regarding their own learning process to direct their studying into productive directions. A combination of self-assessment and peerassessment are often performed together and provides possible advantages such as self-awareness by means of feedback from multiple perspectives. Several studies on relationships among peer, self, and instructor evaluations found that faculty and peer evaluation have a high correlation (Napoles, 2008). When music pre-service teachers are exposed to self-assessment and peer-assessment, they will be actively involved in the learning process and their independence and motivation will improve. David Boud, Lawson, and Thompson (2014) suggested that with the ability to make effective judgements about their own work, students will become effective learners.

Self-assessment refers to the involvement of learners in making judgements about their own learning, particularly about their achievements and the outcomes of their learning". This is because selfassessment and peer-assessment enable teacher trainees to independently assess their own and peers' progress with confidence rather than relying solely on the lecturer's feedback. Teacher training studies which have compared self-evaluation to teacher evaluations, revealed that students rate themselves higher than experts. Neill (2016) found similar outcomes in previous studies amongst university music students (Madsen, Standley, \& Cassidy, 1989).

Assessment involving group task has its own challenges to meet (Johnston \& Miles, 2004), more so during the COVID19 pandemic. Peer-assessment is the assessment of students' work by other students of equal status. It is said to be a powerful meta-cognitive tool as it engages students in the learning 
process and develops their capacity to reflect on and critically evaluate their own learning. Peerassessment is an arrangement for learners to consider and specify the level, value, or quality of a product or performance of other equal-status learners" (Topping, 2009). Pre-service teacher's participation in the assessment process will enhance the development of their professional life as future teachers. Peerassessment in group activities will help pre-service teachers to think critically about revision and improvement and allows them to take control of their own learning.

One of the important instructional functions of peer-assessment is providing detailed feedback. Peer-assessment would help music pre-service teachers by developing their critical thinking, interpersonal skills and enhance understanding within a field of knowledge. As peer-assessment is a formative strategy, it encourages pre-service teachers to comment on their peers' work, improve their understanding of success criteria and help them to become more engaged in learning as well as develop their interpersonal skills. The process undertaken would help music pre-service teachers to reflect on their own efforts and enrich reflection by exchanging feedback on their own and their peers' work. On the other hand, peer-assessment can also have its aftermath as if poor-quality or unhelpful peer feedback is exchanged, it may strain relationships between learners (Topping, 2018).

As peer-assessment become vitally important amongst music pre-service teachers, it is also the role of music lecturers at teacher training institutions to give effective feedback. Guiding music pre-service teachers to provide task-involving feedback (during assessing their peers' work) is more likely to motivate them to learn and improve in their work. Feedback should be task-involving, focusing on key elements of the success criteria that have been met and giving details about how the work might be enhanced. Several research studies have highlighted the importance of teachers' role in modelling how to identify strengths and weaknesses in a peers' work (Min, 2006).

Past research has concentrated on written feedback but students' use of verbal feedback is also an important element (Topping, 2017) whereby peer- assessment may be in a dialogue form rather than in a written manner. A good way would be through exploratory talk where music pre-service teachers think together. This would involve music pre-service teachers asking one another effective questions, reasoning effectively, reaching agreements based on critical discussion and encouraging one another throughout different activities (Mercer \& Sams, 2006). Both exploratory talk and peer-assessment involve hypothesising and reasoning (Topping, 2018).

Peer-assessment can be a valuable learning tool in teacher education because it supports pre-service teachers to acquire skills that are essential in their professional working life. Hence, this study intends to explore music pre-service teacher's self-assessment views in a group task. It is hoped that findings from this study could contribute to the training of future music pre-service teachers.

Though studies on peer-assessment are abundant, those exploring peer-assessment and group work are rather limited. Hence this study hopes to add our knowledge on peer-assessment. The distinction of this study lies in three fold. First, it explores peer-assessment in a group work task. Followed by the peer-assessment was carried out via online, unlike in previous studies where peer-assessment was carried out in a face to face class. Finally the participants of this study were pre-service teachers. The pre-service teachers who took part in this study have taken courses related to assessment. In other words, some of the nook and corners of assessment are exposed to them. Pre-service teachers participating in this study assessed their peer's work with a rubric which was explained before the group task was given.

\section{Methodology}

A key component of the $21^{\text {st }}$ century learning is group work. Besides increasing human interaction, group work allows combining skills and knowledge. Therefore, in a teacher training programme, a number of assignments involves group work. Assignments are broken down to a few tasks. Tasks requiring group work are incorporated in which the skills and abilities of the pre-service teachers are fostered and nurtured. 


\subsection{Participants}

The participants of this study were 30 music pre-service teachers. This study was carried out, when they were enrolled in Music Teaching Method and Approaches course. This course introduces the principles of Kodaly Method and the Orff, and Dalcroze Approaches. The pre-service teachers were expected to plan musical activities that apply this method and the two approaches. This task reinforces pre-service teachers' understanding of musical concepts, and is carried out experientially through singing, playing of musical instruments, music and movement. Pre-service teachers are expected to integrate technology to create teaching aids that would enhance the learning process in an enjoyable and stimulating environment.

Pre-service teachers are assessed through a written exam and assignments See Table 1.

Table-1.

Assessment of Music Teaching Method and Approaches course.

\begin{tabular}{l|l|l|l}
\hline Type & Mode & Approach & \% \\
\hline Written Exam & Individual & Final Exam & 50 \\
\hline \multirow{2}{*}{ Assignment } & \multirow{2}{*}{ Individual } & Critical Review & 10 \\
\cline { 3 - 4 } & & Scripting a musical activity & 20 \\
\cline { 2 - 4 } & & Reflective Writing & 5 \\
\cline { 2 - 4 } & Group & Production - Creative Learning Aid & 15 \\
\hline
\end{tabular}

The group product requires pre-service teachers to write a script and produce a 10-15 minutes puppet show or pantomime video. This task carries $15 \%$ of the overall grades. The pre-service teachers were also given the rubrics on how they would be graded. They are three elements in assessing the video i.e content of the video, creativity and group collaboration in producing the video. The product was assessed holistically by the teacher educator.

\subsection{Peer-Assessment Process}

The focus of this study is to explore the emphasises given by the group members on completing the group task. This study explores the coherence in the emphasise of group members on a tasks. The 30 pre-service teachers were divided into 10 groups. The pre-service teachers were allowed to determine the group members on their own. Being together for almost two years, these pre-service teachers knew each other well. The activity related to peer-assessment was carried out at the end of the semester i.e when all assignment were submitted. Peer-assessment process is relatively new to many of the preservice teachers. Although they have been lectured on classroom based assessments, an activity related to peer-assessment has rarely been conducted. Hence through this study, pre-service teachers are introduced to one form of peer-assessment.

To familiarize with the process, all the pre-service teachers were asked to assess individually one group's product i.e video. To facilitate the assessment, a score sheet was provided to each pre-service teachers (See Attachment). The score sheet was collated and the average marks of each group was calculated. Average marks was calculated for each criteria and the overall marks too.

This study was carried out during the Movement Control Order (MCO) imposed by the government. MCO was implemented to curb the spread of Corona Virus. The pre-service teachers assessed the product via online. The selected product was uploaded and the pre-service teachers were

given the url. Before viewing the video, pre-service teachers were briefed on the rubrics. This was followed by the viewing. After viewing, the pre-service teachers were asked to record their assessment via a google form.

\section{Findings}

Nine group i.e 27 pre-service teachers assessed a group's product. Three pre-service teachers, whose group product was used, were excluded. As required, pre-service teachers were required to award a 
mark for the product. The maximum awarded for this group task is 15 . To obtain a group's mark, an average mark was calculated. Table 2 shows the average marks of the nine groups. The lowest mark was 11.33 , by Group 3 pre-service teachers, and the highest was 13.50, by Group 1. Further scrutiny shows pre-service teachers of Group 6 has the highest range of marks. The difference among the three pre-service teachers is 2.8, while the pre-service teachers of group 7 has given similar mark i.e 13 .

Table-2.

Product Marks Awarded (average).

\begin{tabular}{c|c|c}
\hline Group & Marks (Average) & Range \\
\hline 1 & 13.50 & 2.5 \\
\hline 2 & 13.33 & 3 \\
\hline 3 & 11.33 & 4 \\
\hline 4 & 13.33 & 1 \\
\hline 5 & 12.67 & 1.5 \\
\hline 6 & 12.50 & 2.8 \\
\hline 7 & 13 & - \\
\hline 8 & 12 & 2 \\
\hline 9 & 12.67 & 1 \\
\hline
\end{tabular}

Further exploration on the criteria used to assess the product is depicted in Figure 1. Pre-service teachers' of Group 2 shows their comprehension and expectation of the three criteria are the most coherence. Pre-service teachers' of five groups i.e Group 1, Group 5, Group 7, Group 8 and Group 9 had awarded the same marks for all the three criteria. This is coherent with the findings of Nahapiet and Ghoshal (1998). Their study noted that coordinated discussion among the group members will create a better understanding of the given task. As mentioned earlier, the pre-service teachers were allowed to pick their own group members. Though it is difficult to prove, being together for more than 2 years enabled the pre-service teachers to identify with whom they could work with.

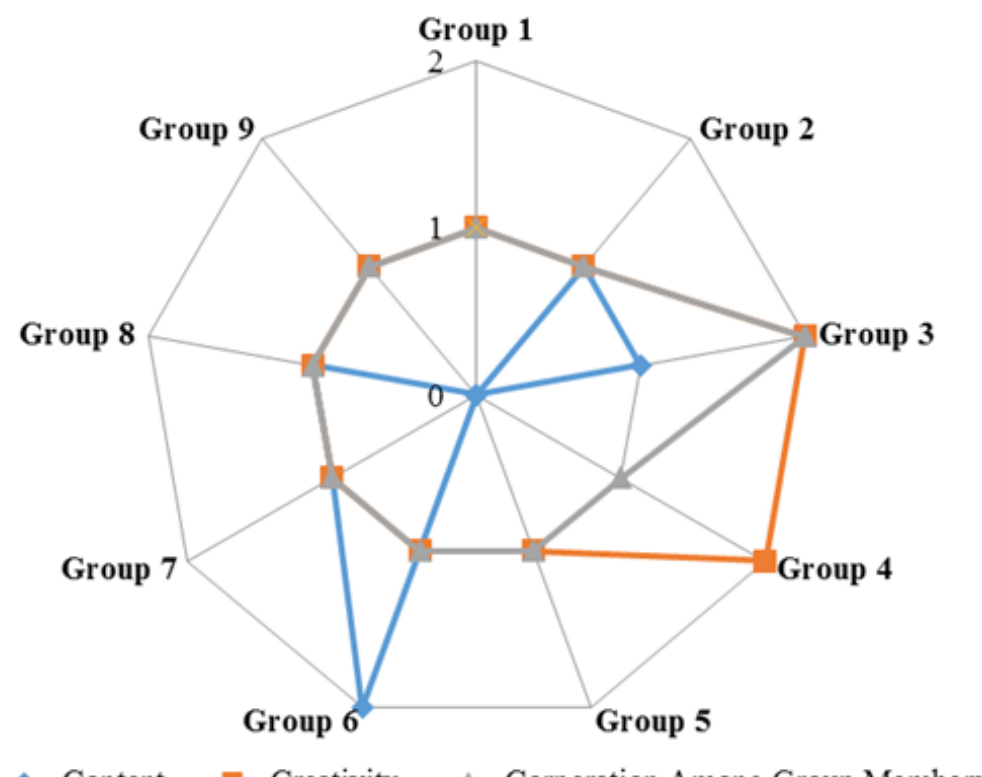

Figure-1.

Assessment Based on Criteria. 
Among the three criteria, creativity caused the most difference among the group members. Preservice teachers' of Group 3 and Group 4, the range of difference is 2. On the other hand, criteria on content caused the least difference among the group members. There is no difference among five groups pre-service teachers i.e Group 1, Group 4, Group 5, Group 7 and Group 9.

For the content, story board played a key role in determining the marks awarded. All pre-service teachers emphasized the need to have a story which is suitable and relevant to the audience. Since the video was meant for school children, stories which children could relate easily were given priority. Stories which were narrated with good animation were considered to display creativity. Pre-service teachers' of Group 1, Group 5, Group 7, Group 8 and Group 9 were of the same opinion that the product which they assessed lacked animation, thus diminishing creativity score. On the other hand preservice teachers' of Group 3 and Group 4, associated creativity with the technology and $21^{\text {st }}$ century learning. While some in the group complimented the product for the application of technology in producing the video, there were others in the group who had a different view on the technology usage. Nevertheless many in the group viewed the product displayed good $21^{\text {st }}$ century learning attributes.

\section{Policy Recommendations}

The key focus of this study is peer-assessment of a task involving group work. Bloxham, Hudson, Outer, and Price (2015) believed such practices would regulate and assure academic standards are met. Hence being pre-service teachers, this augurs well for their future career as teachers. The Covid 19 pandemic had forced many educators to embrace digital technologies to deliver their lessons. There is pressing need for teachers to have the necessary skills and knowledge to deliver their lesson efficiently and effectively (Godvin, 2020). The current teacher training contents were developed prior to the pandemic. Skills and knowledge related to online pedagogy should be looked into more. Teacher training content developers should include elements which equip teachers to embrace technologies which are fast evolving. Instead of just training teachers with the current teaching platform, teachers should be able to adapt and adopt new technologies easily. Suggestions by Martin, Wang, and Sadaf (2018) on how to facilitate distance learning could be incorporated in the course content of teacher training. The four aspects are technical, pedagogical, social and managerial.

Being future teachers, pre-service teachers must be exposed to appropriate pedagogic techniques related to group tasks. Pre-service teachers should be able to develop effective group and team work skills among their students. In doing so, pre-service teachers will need to assess the development of non-academic skills of their students (Gammie \& Matson, 2007). For instance Song, Lim, and Kwon (2021) advocate the usage of asynchronous and synchronous methods in teaching. Hence pre-service teachers must be exposed to what constitutes as asynchronous methods and what are synchronous methods. Prior to this, teacher trainers must be familiar with these concepts and must be seen using them in delivering their courses too. One way of ensuring pre-service teachers use these methods is by spelling it out in the course syllabus clearly.

Through many courses, these pre-service teachers are exposed to the benefits, advantages, disadvantages and procedures adhere to when doing group task. However issues related to assessment of group task are rather limited. In fact utilising peer-assessment as a tool to assess group task is almost unheard to many.

There are three reasons, peer-assessment brings to learning. It helps students value peer learning, motivates peer learning and enhance working collaboratively (Pitt, 2000). One of the challenges in group work is eliminating 'free-riders' in group task (Heathfield, 1999). The findings of this study shows 'cooperation among students', a criteria used to assess group has the lowest range among the preservice teachers. This shows that pre-service teachers are able to judge contribution and cooperation among group members in co (Kılıç, 2016)mpleting a group task. Being future teachers, pre-service teachers would be able to use this skill in assessing group task. 


\section{References}

Bathgate, M., Sims-Knight, J., \& Schunn, C. (2012). Thoughts on thinking: Engaging novice music students in metacognition. Applied Cognitive Psychology, 26(3), 403-409. Available at: https://doi.org/10.1002/acp.1842

Bloxham, S., Hudson, J. D., Outer, B., \& Price, M. (2015). External peer review of assessment: An effective approach to verifying standards? Higher Education Research छ Development 34(6), 1069-1082. Available at: https://doi.org/10.1080/07294360.2015.1024629.

Boud, D., \& Falchikov, N. (2007). Rethinking assessment in the learning for the longer term. Abingdon: Routledge.

Boud, D., Lawson, R., \& Thompson, D. G. (2014). The calibration of student judgement through self-assessment: Disruptive effects of assessment patterns. Higher Education Research $\mathcal{E}^{\circ}$ Development, 34(1), 45-59. Available at: https://doi.org/10.1080/07294360.2014.934328.

Davis, B. D. (1993). Collaborative learning: Group work and Study teams. Tools for teaching. San Francisco: Jossey-Bass.

De Grez, L., Valcke, M., \& Roozen, I. (2012). How effective are self and peer assessment of oral presentation skills compared with teachers' assessment? Active Learning in Higher Education, 13(2), 129-142. Available at: https://doi.org/10.1177/1469787412441284.

Falchikov, N. (2005). Improving assessment through student involvement. London: Routledge.

Gammie, E., \& Matson, M. (2007). Group assessment at final degree level: An evaluation. Accounting Education, 16(2), $185-206$. Available at: https://doi.org/10.1080/09639280701234609.

Godvin, C. (2020). Interest group: Independent school art education. NAEA Neres, 62(3), 1-40. Available at: https://doi.org/10.1080/01606395.2020.1757973.

Heathfield, M. (1999). Group-based assessment: An evaluation of the use of assessed tasks as a method of fostering higher quality learning. In S. Brown, \& A.Glasner, Assessment matters in higher education: Choosing and using diverse approaches. Assessment matters in higher education: Choosing and using diverse approaches (pp. 132-145). Buckingham, UK: Society for Research into Higher Education and Open University Press.

Johnston, L., \& Miles, L. (2004). Assessing contributions to group assignments. Assessment and Evaluation in Higher Education, 29(6), 75 1-768. Available at: https://doi.org/10.1080/0260293042000227272.

Kılıç, D. (2016). An examination of using self-, peer-, and teacher-assessment in higher education: A case study in teacher education. Higher Education Studies, 6(1), 136-144. Available at: https://doi.org/10.5539/hes.v6n 1p136.

Madsen, C. K., Standley, J. M., \& Cassidy, J. W. (1989). Demonstration and recognition of high and low contrasts in teacher intensity. Journal of Research in Music Education, 37(2), 85-92. Available at: https://doi.org/10.2307/3344700.

Martin, F., Wang, C., \& Sadaf, A. (2018). Student perception of helpfulness of facilitation strategies that enhance instructor presence, connectedness, engagement and learning in online courses. Internet and Higher Education, 37(1), 52-65. Available at: https://doi.org/10.1016/j.iheduc.2018.01.003.

Mercer, N., \& Sams, C. (2006). Teaching children how to use language to solve maths problems. Language and Education, 20(6), 507-528. Available at: https://doi.org/10.2167/le678.0.

Min, H.-T. (2006). The effects of trained peer review on EFL students' revision types and writing quality. Journal of Second Language Writing, 15(2), 118-141. Available at: https://doi.org/10.1016/j.jslw.2006.01.003.

Nahapiet, J., \& Ghoshal, S. (1998). Social capital, intellectual capital, and the organizational advantage. Academy of Management Review, 23(2), 242-266. Available at: https://doi.org/10.5465/amr.1998.533225.

Napoles, J. (2008). Relationships among instructor, peer, and self-evaluations of undergraduate music education majors' microteaching experiences. Journal of Research in Music Education, 56(1), 82-91. Available at: https://doi.org/10.1177/0022429408323071.

Neill, S. L. (2016). Effects of peer and self-evaluations on pre-service teaching experiences. International Journal of Music and Performing Arts, 4(2), 31-37. Available at: https://doi.org/10.15640/ijmpa.v4n 1 a3.

Nikoleizig, L., Schmukle, S. C., Griebenow, M., \& Krause, S. (2021). Investigating contributors to performance evaluations in small groups:Task competence, speaking time, physical expressiveness, and likability. PLoS ONE, 6(16), 1-17. Available at: https://doi.org/10.1371/journal.pone.0252980.

Pitt, M. J. (2000). The application of games theory to group project assessment. Teaching and Learning in Higher Education, 5(2), 233-241. Available at: https://doi.org/10.1080/135625100114876.

Song, B., Lim, K., \& Kwon, H. (2021). Insights from three online art educators: Strategies for instruction. Interaction, and Assessment. Art Education, 74(4), 16-2 1. Available at: https://doi.org/10.1080/00043125.2021.1905399.

Stanley, A. (2011). Professional developmet within collaborative teacher study groups: Pitfalls and promises. Arts Education Policy Review, $112(2), 71-78$. Available at: https://doi.org/10.1080/10632913.2011.546692.

Topping, K. J. (2009). Peer assessment. Theory Into Practice, 48(1), 20-27.

Topping, K. J. (2017). Peer assessment: Learning by judging and discussing the work of other learners. Interdisciplinary Education and Psychology, 1(7), 1-17. Available at: https://doi.org/10.31532/interdiscipeducpsychol.1.1.007.

Topping, K. J. (2018). Learning by peer assessment: Appraising, reflecting, discussing. New York and London: Routledge. 